\title{
Possibilities of heat energy recovery from greywater systems
}

\author{
Kaja Niewitecka ${ }^{1, *}$ \\ ${ }^{1}$ Faculty of Building Services, Hydro and Environmental Engineering, Warsaw University of \\ Technology, 20 Nowowiejska Street, 00-653 Warsaw, Poland
}

\begin{abstract}
Waste water contains a large amount of heat energy which is irretrievably lost, so it is worth thinking about the possibilities of its recovery. It is estimated that in a residential building with full sanitary fittings, about $70 \%$ of the total tap water supplied is discharged as greywater and could be reused. The subject of the work is the opportunity to reuse waste water as an alternative source of heat for buildings. For this purpose, the design of heat exchangers used in the process of greywater heat recovery in indoor sewage systems, public buildings as well as in industrial plants has been reviewed. The possibility of recovering heat from waste water transported in outdoor sewage systems was also taken into consideration. An exemplary waste water heat recovery system was proposed, and the amount of heat that could be obtained using a greywater heat recovery system in a residential building was presented. The work shows that greywater heat recovery systems allow for significant savings in preheating hot tap water, and the rate of cost reimbursement depends on the purpose of the building and the type of installation. At the same time, the work shows that one should adjust the construction solutions of heat exchangers and indoor installations in buildings to the quality of the medium flowing, which is greywater.
\end{abstract}

\section{Introduction}

Increasing demand for energy, observed all over the world, forces to take action aiming at managing it more effectively. In Poland, a new approach to energy management results from imposed by the European Union country's commitment concerning the improvement of energy efficiency by increasing the share of renewable energy sources and reducing the negative impact of energy economy on the environment. One of the practical ways allowing to achieve these goals is to use waste heat from waste water.

Currently, many European countries are implementing technical solutions allowing to restore a portion of the lost heat and manage the recovered energy as an alternative source of energy for a building, for instance, to preheat water, heat the buildings or as a source of chill for air conditioning during summer. All this can be achieved using suitable devices such as heat exchangers, which can be installed both in buildings and in sewage systems.

\footnotetext{
*Corresponding author: kaja.niewitecka@pw.edu.pl
} 
Recently, what is gaining popularity in Poland are so-called "nearly zero-energy" buildings, where one of many technical solutions to reduce energy consumption could be the heat recovery from the underrated energy which is greywater. Yet, this is still an innovative issue, rarely applied in Poland. Literature indicates, however, that this form of waste energy use has its own energy, environmental and economic justification.

\section{Legal regulations of greywater use}

The use of greywater as an alternative energy source in a building is not subject to any specific legal regulations in Poland. Thinking about waste water heat recovery, we have to distinguish two concepts: grey sewage and black sewage. These concepts are defined in the Polish standard PN-EN 12056-1: 2002P. What is meant by the term "black sewage water" is cold waste water discharged from toilet bowls and urinals, at the temperature of about $10^{\circ} \mathrm{C}$. The "grey sewage water", however, is the outflows from bathtubs, showers, washbasins, automatic washing machines or dishwashers. They contain less pollutant load and their temperature is higher (about $30^{\circ} \mathrm{C}$ ). In the regulations an important reference for the possibility and purpose of the use of grey sewage is the record in the standard PN-EN 12056-1: 2002, which classifies a sewer system discharging grey and black sewage by separate sewage systems (so-called system IV). Therefore, in order to use the energy potential of grey sewage discharged from the building, it is necessary to start with separating the sewage system. This will allow waste water heat recovery system to be mounted on the grey sewage drain tube [1].

Modern technologies allow for the collection of heat from waste water also at the stage of their transportation to the sewage treatment plant, i.e. in the collector pipe. This idea, however, is met with negative opinions, and this is related to the reduction of the temperature of sewage before their inflow to the sewage treatment plant, which can adversely affect the biological processes ongoing there [2].

Waste water heat energy can be obtained in several places in the sewage system: near the place of their formation and their outlet to the sewage system, at the stage of their transportation, i.e. in the collector pipe, and at the outlet of the collector from the sewage treatment plant [3].

\section{Energy potential of sewage}

The parameters that characterize waste water in terms of their energy potential are, first of all, their temperature and quantity. The next criteria assessing the waste water energy potential are their quality, technical condition of the sewers, the distance between the heat recovery system and the customers, as well as the type of customers and their energy needs [4].

The actual amount of greywater discharged from residential buildings depends on many factors such as the price of water, the quantity and quality of sanitary utensils, the habits of the residents, and the devices used in buildings to reduce water consumption. The amount of greywater discharged from the average household is about $60 \mathrm{dm}^{3} / \mathrm{Md}$. Their average temperature is about $30^{\circ} \mathrm{C}[1]$.

On the other hand, the average temperature of domestic waste already in the sewage system is about $15^{\circ} \mathrm{C}$. Over the summer it reaches $20^{\circ} \mathrm{C}$ and can be successfully used as an alternative energy source. Compared to other low temperature heat sources used as the lower energy source for heat pumps (soil, soil water with a temperature $7-13^{\circ} \mathrm{C}$ ), waste water is distinguished by relatively high temperature throughout the year [4]. 
Apart from residential buildings, industrial plants have a high energy potential in terms of the amount and the temperature of waste water discharged. In many of them, technology is based on the processes in which high-temperature water is used. In the case of the textile industry there are so-called hot baths, and in the laundry facilities there is a lot of washing and rinsing [5]. Industrial waste is characterized by significantly higher temperatures in comparison to domestic waste. In addition, in accordance with the Regulation of the Minister of Construction on the realisation of the obligations of industrial waste water providers and the conditions of discharging sewage into sewerage devices [6], the temperature of sewage from industrial plants discharged to sewerage devices must not be more than $35^{\circ} \mathrm{C}$. This is another argument that encourages to manage the heat from industrial waste water.

Other facilities where heat recovery may be a good solution are public buildings such as indoor swimming pools or hotels. In such facilities, large amounts of warm waste water are discharged into the sewer system and replaced by fresh warm water. An excellent source of energy to manage is the used water from swimming pools. Warm sewage comes mainly from showers, filter rinsing, and pool drainage. Their temperature is respectively [7]:

- 39-41 ${ }^{\circ} \mathrm{C}$ for waste water from showers,

$-25-26{ }^{\circ} \mathrm{C}$ for outflows from swimming pools,

- 28-30 ${ }^{\circ} \mathrm{C}$ for outflows from recreational pools,

- 30-32 ${ }^{\circ} \mathrm{C}$ for outflows from children's pools,

$-25-35{ }^{\circ} \mathrm{C}$ for rinse water from filters.

The average swimming pool produces about 30,000 liters of "grey" sewage per day. Such an amount causes a reflection on the use of a heat recovery system. However, a significant problem arising here is considerable pollution of used swimming pool water with slurry, fats, detergents, hair.

\section{Possibilities of heat recovery from sewage}

\subsection{Heat recovery from internal installations}

Much of the heat lost with sewage can be recovered and managed at the place where it was produced by installing a special exchanger. Exchangers used in sewage systems making heat energy recovery possible are called Drain Water Heat Recovery (DWHR). Of all types of DWHR, the devices in vertical systems are the most effective and most frequently used. They work as countercurrent exchangers (of opposite flow directions). Among them there are spiral heat exchangers and "pipe-in-pipe" exchangers. Vertical systems are manufactured by numerous manufacturers, mainly in the United States, Canada, Norway and the United Kingdom [8].

Spiral heat exchangers are anything but a drain pipe made of copper with a larger diameter, which discharges the used water from sanitary utensils, around which a copper tube is wound through which cold water flows in the opposite direction. The spiral is smaller in diameter than the drain pipe and, additionally, at the point of contact it is flattened, which increases the contact surface of both liquids and enables a more efficient transfer of heat from the effluent into the water. Spiral exchangers have been applied by many companies, but they vary in diameter, length of drains $(70-200 \mathrm{~cm})$ and the degree of flattening the pipes and the efficiency (30-65\%). The diagram of the spiral heat exchanger is presented in the figure 1 . This is a single copper pipe with a diameter of $18 \mathrm{~mm}$ spirally wrapped around a downpipe with a diameter of $110 \mathrm{~mm}$. The length of the device is $100 \mathrm{~cm}$. According to the producent, thanks to the use of such an exchanger, we can recover $40-60 \%$ of the energy lost with sewage, and thus reduce the cost of preheating water by up to $40 \%$ [9]. 


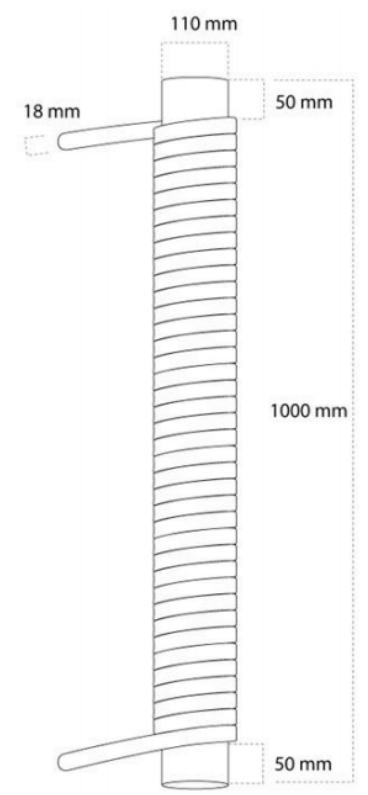

Fig. 1. A spiral heat exchanger - Ecoteb 110-100-01011.

The alternative for spiral exchangers are "pipe-in-pipe" exchangers. The components constituting this device are two pipes, the inner one of a smaller diameter and the outer one which forms a casing of the device. Heat is transferred between warm sewage flowing through the inner tube and tap water flowing in the space between the sewage transfer pipe and the outer pipe. Sewage flows down the inside of the drain pipe. The principle of operation of a "pipe-in-pipe" exchanger is presented in the figure 2 . The efficiency of exchangers is about $60 \%$. For larger installations with the flows that exceed the operating range of a single exchanger, combinations of devices cooperating with each other are provided.

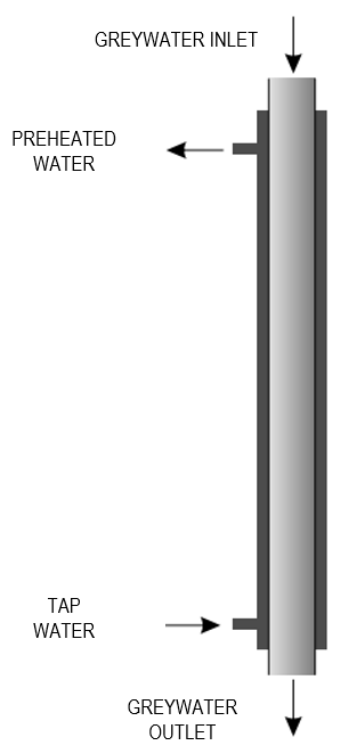


Fig. 2. A "pipe in pipe" heat exchanger.

\subsection{Heat recovery from sewage systems}

Heat from sewage can also be received at the stage of its transportation, i.e. in the collector. The average annual temperature of household waste is about $18-20^{\circ} \mathrm{C}$ in the summer and about $10-12{ }^{\circ} \mathrm{C}$ in the winter. When using special heat exchangers and with cooperation of a system with a heat pump, a large amount of heat energy can be recovered for use. In many European cities such as Paris, Hamburg and Oslo, a sewage recovery system has been applied. Research in this direction was already conducted in the 80's in Switzerland. The first designs of devices were quite expensive to invest in, and the warm pumps used at that time were of poor operational efficiency, but nowadays the solutions are gaining more and more interest and their profitability is increasing.

Heat exchangers are available as built into the structure of sewage pipe, used in the case of new constructed collectors, as well as ones for the use on the existing collectors, at the stage of the renovation, mounted by using a trenchless technology [10].

The first ones are most commonly used for newly built pipes, but also at the stage of replacing the used with new ones. The exchangers mentioned are most often polyethylene or corrosion resistant steel pipes, placed on the bottom of the collector in a profiled halfround gutter of a concrete or reinforced concrete pipe. They are characterized by high structural durability and long heat storage capacity. Their efficiency is in the range of 1-2 $\mathrm{kW}$ per tube length meter. Exemplary solutions are shown in the figure 3.

Modern technologies allow the exchanger to be built into existing collectors at the stage of their renovation using trenchless methods. The most commonly used solutions are readymade modules that can be mounted in the collector. The discretion to combine them in stretches of any length and low investment cost make this technology very popular. The exchanger design is an arc-shaped profile under which two or three polyethylene tubes, in which intermedium circulates, are fixed. The minimum required efficiency of $20 \mathrm{l} / \mathrm{s}$ provides thermal efficiency of up to $2 \mathrm{~kW} /$ tube length meter [2]. An example of such a solution is presented in the figure 4.
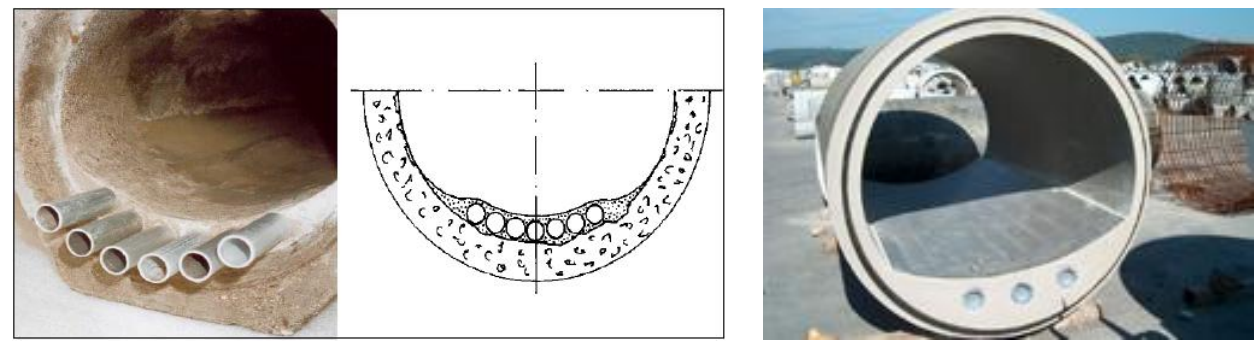

Fig. 3. Heat exchangers built into the structure of sewage pipe.
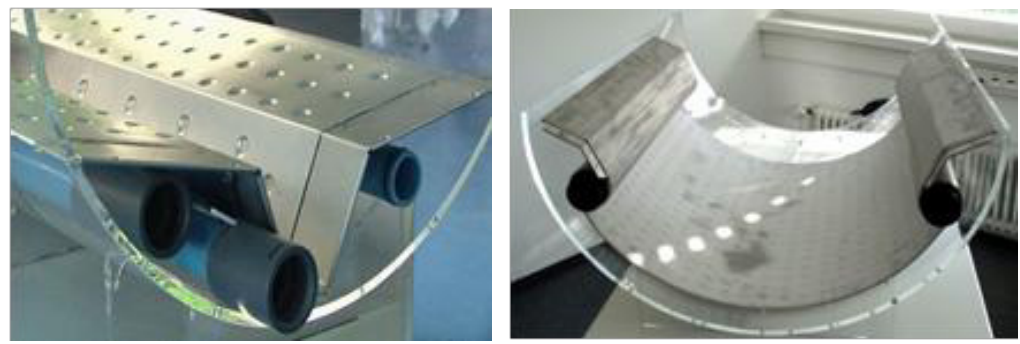

Fig. 4. Ready-made modules of heat exchangers for the use on the existing collectors. 
Each heat exchanger used in the collector must be resistant to the aggressive effects of sewage, so they are made of materials such as polyethylene, stainless steel and they are often also additionally enclosed.

In order to use energy from the sewage transported by the collector, the heat recovery is done using heat pumps. Sewage flowing in the sewer pipe gives back the heat on the length of the pipe with the heat exchanger mounted. The process involves taking over heat by intermedium flowing through the heat exchanger placed in the collector. It may be glycol, brine or even water, which is then directed to the heat pump located in the boiler room at the customer's house or in the boiler room serving the larger area (district).

At present, heat recovery technology from sewage collectors is an unknown and very innovative solution in Poland. At the same time, there are numerous examples of its use in Western European countries and continuous development in this field, as well as the growing interest in acquiring such energy, are conducive to the implementation of such solutions in our country.

\section{Exemplary waste water heat recovery system}

The use of energy from sewage as an alternative energy source to preheat water for buildings can be realized by using the presented heat exchangers cooperating with the heat pump. In order to increase the efficiency of heat recovery system from waste water, especially in larger installations, each heat recovery system should consist of the following components:

- wastewater retention tank - necessary because of the irregularity of waste water discharges and their varied quantity within 24 hours,

- hot tap water tank - to store fresh water for further use,

- sewage filter - is intended to stop pollution, located in front of the retention tank,

- heat recovery system - a heat exchanger and a heat pump.

An exemplary waste water heat recovery system is shown in the figure 5.

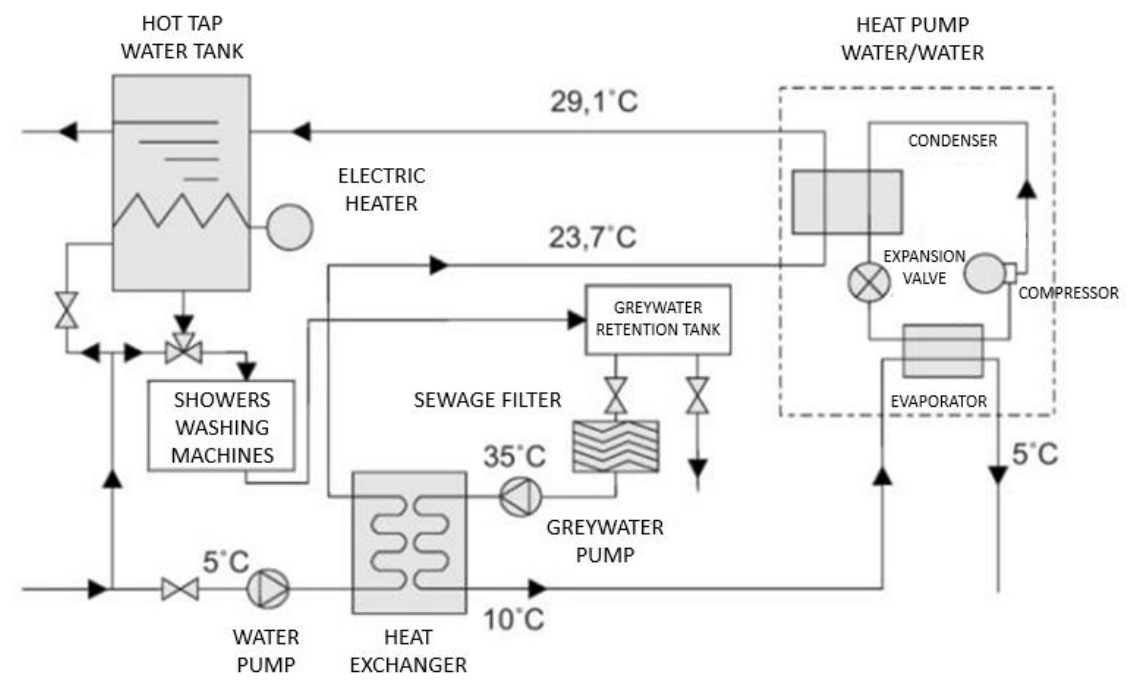

Fig. 5. An exemplary greywater heat recovery system [5]. 
Particularly noteworthy is the possibility to reduce charges related to the preparation of domestic hot water. In the average household in Poland, the second largest item in fees for energy is the cost of preparing hot water.

For example, when using a spiral 50\% efficiency heat exchanger recovering heat from the grey effluents obtained only from a shower (the temperature of waste water is $38^{\circ} \mathrm{C}$ ) in a single-family dwelling inhabited by 5 people, the amount of energy saved for preheating water is about $1100 \mathrm{kWh}$, which gives cost savings of 580 PLN. Taking into account the total investment costs including the purchase price and the installation of the device as well as the costs resulting from the operation of the system during the warranty period (total: 4000 PLN), the costs would return within 7 years of using the system.

\section{Summary}

All over the world new sources of heat as well as modern solutions allowing for waste heat recovery are being looked for. Recovering energy from sewage will not solve the problem of rising energy demand, but it can contribute to some savings in this field.

The presented overview of construction solutions of waste water heat recovery devices shows the multidimensionality of their applications. Universal solutions that will appeal both to homeowners and industrialists are being looked for.

The innovative solution is to obtain energy in the sewage collectors. Studies show that systems of this type can be profitable due to the ease and low costs of acquiring a new heat source.

On the other hand, as for now, no mention is made of the possible effects of the reduction of the temperature of sewage as a result of heat recovery before their inflow to the treatment plant. In addition, due to the lack of data on the quality of greywater, there are concerns about their impact on the efficiency of devices (operation problems - blocking of pipes, pumps), as well as the natural environment.

There is no doubt, however, that the installation of a DWHR exchanger can contribute to saving the energy used to prepare hot tap water. Obviously, in the case of a detached house the benefits are small. Greater savings can be anticipated where large amounts of water are used, and therefore, the amount of waste water discharged is greater or it is discharged more frequently.

It should also be mentioned that the presented solutions are innovative, still rarely found in our country. Currently, the work is being done on improving these devices, increasing their efficiency and it can be expected that their attractiveness will increase over time.

\section{References}

[1] J. Chudzicki, Techniczne możliwości oszczędzania wody $i$ energii $w$ budynkach użyteczności publicznej - wnioski ze STEP-u, Energia i Budynek, 2, 22-25 (2011)

[2] P. Kuliczkowski, Rodzaje wymienników ciepła stosowanych $w$ kolektorach kanalizacyjnych umożliwiających odzysk ciepła ze ścieków, Instal, 12, 46-49 (2009)

[3] E. Müller, F. Schmid, W. Stodtmeister, B. Kobel, Ratgeber für Bauherrn Und Kommunen, Heizen und Kühlen mit Abwasser (2005)

[4] W. Joniec, Odzysk ciepta z kanalizacji, Rynek Instalacyjny, 5, 72-75 (2007) 
[5] S. Kordana, D. Słyś, Odzysk ciepta odpadowego $w$ instalacjach $i$ systemach kanalizacyjnych, Wydawnictwo i Handel Książkami „KaBe”, Krosno (2013)

[6] Journal of Laws 2006 No. 136, item 964, as amended

[7] A. Kolaszewski, Odzysk ciepła ze ścieków w krytej pływalni, Materiały Budowlane, 2, 48-49 (2000)

[8] A. Kimmels, Shower Heat Recovery: Overview of Commercially Available DWHR Systems, Meander Heat Recovery (2011)

[9] Cooperman, J. Dieckmann, J. Brodrick, Drain Water Heat Recovery, ASHRAE Journal, 11, 58-62 (2011)

[10] P. Kuliczkowski, Alternatywne pozyskiwanie energii z kanatów sanitarnych za pomoca technologii bezwykopowych, Nowoczesne Budownictwo Inżynieryjne, 3/4, 55-58 (2010) 